\title{
The Academy through Epicurean Eyes: Some Lives of Academic Philosophers in Philodemus' Syntaxis
}

One of the stated goals of this conference is to provide a 'survey of the evidence' for Plato’s Academy. This evidence can take many forms, philosophical, historical, literary, even material - all equally important if we are to form a complete picture of Plato's school, its evolution, its internal workings and its influence on and interaction with those outside it. Out of all these different types of evidence, I have chosen to focus on History of the Academy by the $1^{\text {st }}$-century BC Epicurean philosopher Philodemus of Gadara ( $\Gamma \alpha ́ \delta \alpha \rho \alpha)$, a text on which there is a certain amount of consensus that it formed part of his

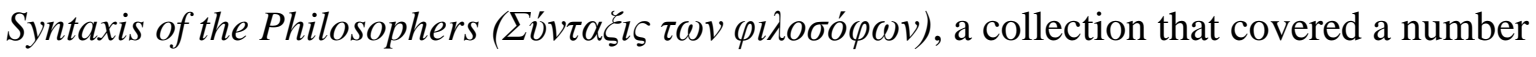
of different schools, including the Stoics and his own Epicurean school. Apart from the very important factual information that Philodemus offers on individual Academics, this text is also of interest because of the questions it raises about what 'the Academy' represented for an ancient philosopher who was never its member: what did an Epicurean who was contemporary with the last phases of the Academy consider most worth recording and what sort of picture did he paint of the Academic tradition? In what follows I will highlight some ways in which Philodemus can be particularly informative not only for raw data about the Academy itself, but also for the ways in which its history was perceived from the outside.

First of all, let me say a few words about the text itself, its contents, its difficulties and peculiarities. It survives on two carbonised papyri from Herculaneum, from the Villa of the Papyri that has yielded so many other texts by Philodemus and other Epicurean authors. It was initially published under the title Academicorum Index ${ }^{1}$ and was subsequently identified as part of the larger work in at least 10 books cited by Diogenes Laertius ( $\Delta$ 1o

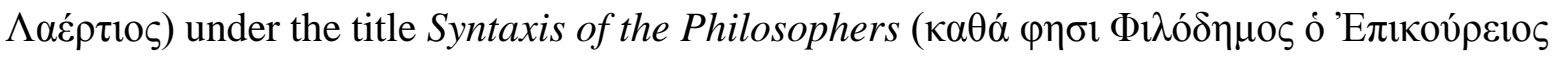

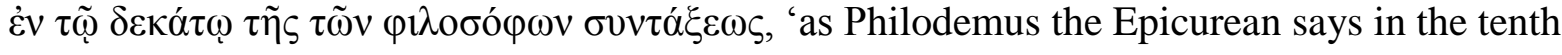
book of his Collection/System of Philosophers', D.L. 10.3). ${ }^{2}$ The History of the Stoa, traditionally known as Index Stoicorum, which preserved on an even more badly damaged papyrus and thus offering less information on the Stoics than we have on the Academics, has also been identified as part of the same work.

\footnotetext{
${ }^{1}$ Mekler, S. (ed,) Academicorum Philosophorum Index Herculanensis. Berlin 1902, 1958.

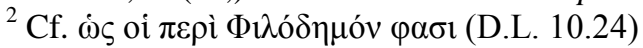


Of the two papyri preserving the history of the Academy, PHerc. 164 consists only in 30 or so small fragments, and it is very hard to place them in sequence or even to judge whether any of them come from the same column. Most of what we now read comes from the other papyrus, PHerc 1021, from which we have substantially more material, in fact there are 36 columns preserved, in various degrees of legibility. But this papyrus presents difficulties of its own, making it hard for scholars to reconstruct the order of the columns from the preserved carbonised pieces and the Oxford and Naples apographs (copies that were handmade very close to the time of unrolling). Many of these difficulties are due to the fact that PHerc. 1021 represents a rough draft, a fairly early stage when Philodemus was still gathering and working on his material on the Academics (scholars agree that the small fragments from PHerc. 164 represent a later stage of the composition process). This is why in PHerc 1021 we find many marks of correction, additions and transpositions, as well as 'unprocessed' quotations from authors such as Dicaearchus ( $\Delta 1 \kappa \alpha i \alpha \rho \chi \rho \varsigma)$, Antigonus of

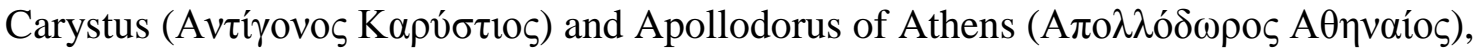
without much introduction or intervention by Philodemus himself. Moreover, as Gallo and Cavallo showed in 1983, ${ }^{3}$ some of the columns preserved by the Oxford apograph were in fact written on the back (the verso) of the original papyrus, making the reconstruction of the order of the text even more complicated. These difficulties with the sequence make it harder to trace a continuous and consistent train of thought, and we should also be aware of the long source citations which indicate that a lot of the time we may not actually be reading Philodemus’ own words. Nevertheless, Arrighetti has recently argued that even the finished version would have retained these long quotations (in the manner of other roughly contemporary scholarly works such as Didymus’ commentary on Demosthenes, also preserved on papyrus $)^{4}$ and therefore we may feel some confidence that what we can read is at least close to Philodemus' intended final product.

Moving on from the condition of the text to the contents of what does survive from Philodemus' history of the Academy, we are faced with a further set of questions, namely what type of work was Philodemus' Syntaxis and more specifically what were his aims and methods in discussing Plato's Academy and what, if any, difference is made by his 'outsider', Epicurean standpoint. It quickly becomes clear that categorising the work in terms of genre will not be straightforward. It is not simply a work of biography - even though we often

\footnotetext{
${ }^{3}$ I. Gallo, 'Sulla struttura di PHerc. 1021', CErc 13 (1983): 75-9; G. Cavallo, Libri scritture scribe a Ercolano. Naples 1983: $61 \mathrm{f}$.

${ }^{4}$ Arriggetti, G. 'Filodemo biografo dei filosofi e le forme dell’ erudizione’, CErc 33 (2003): 13-30.
} 
speak of its different sections as the 'Life of Plato', the 'Life of Speusippus' ( $\Sigma \pi \varepsilon v ́ \sigma 1 \pi \pi \circ \varsigma)$, the 'Life of Philo’ (Фí $\Lambda \omega v$ ) etc. Based on Dorandi’s calculations, of the 36 surviving columns, 11 are devoted to Plato and events during his lifetime, then 2-3 to each of Speusippus, Xenocrates, Heracleides of Pontus, Chaeron of Pellene, Polemo and Crantor

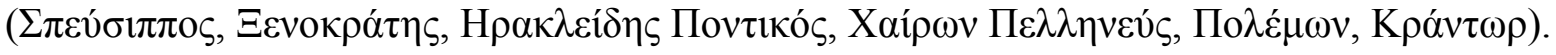
Following brief notices on Adeimantus of Aetolia and Crates of Athens (A $\delta \varepsilon i ́ \mu \alpha v \tau o \varsigma$

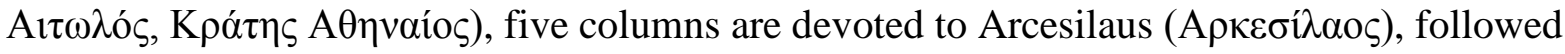

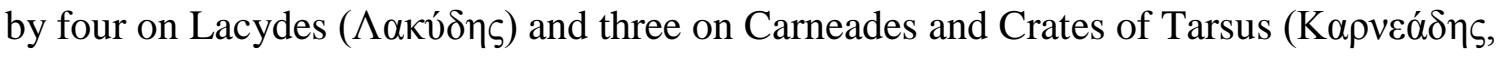

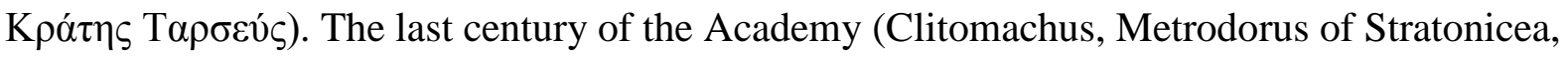

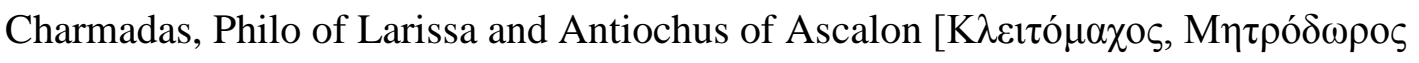

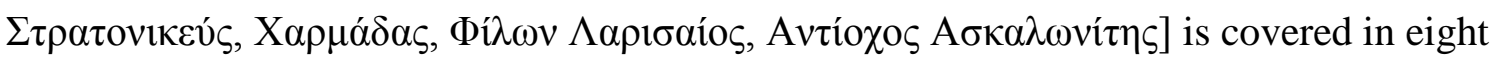
columns). Despite substantial gaps due to illegible sections of the papyrus, we can tell that there are significant variations in the length at which each of these Academics is treated by Philodemus.

Some of the material that accounts for the greater length of some 'Lives' can be traced back to the tradition of Hellenistic biography of Peripatetic / Callimachean pedigree. Such features include (i) biographical anecdotes (for example the story that Plato was once sold as a slave in Aegina or that Xenocrates won a drinking contest and offered the prize, a golden wreath, to a statue of Hermes); (ii) an interest in listing and distinguishing between authors and other notable personalities of the same name, a trend best illustrated in the Пвpi

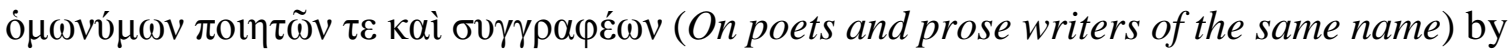
Demetrius of Magnesia (dated in the $1^{\text {st }}$ century BC, cited several times by Diogenes Laertius); (iii) scholarly precision indicated by the citation of named sources. There are also some traces of the interest in personality traits and psychological developments that would later become commonplace in 'didactic' biography (Plutarch, Suetonius etc.) - for example Philodemus (like Diogenes Laertius) cites Antigonus of Carystus for the story of Polemo's drunken and violent exploits as a youth, and how he was then turned by Xenocrates' teaching into a paradigm of $\alpha \tau \alpha \rho \alpha \xi i$.

Another feature that adds substantially to the length of certain sections (such as the ones on Plato, Lacydes and Arcesilaus) is the presence of long lists of pupils or disciples, which is also evident in what remains from Philodemus' work on the history of the Stoa. This special attention to teacher-pupil relationships is not associated with Hellenistic biography so much as with the separate genre of 'Successions' ( $\Delta 1 \alpha \delta o \chi \alpha i)$, which flourished in the Hellenistic period with authors such as Sotion, Sosicrates, Hippobotus and Antisthenes ( $\Sigma \omega \tau i$ ív, 


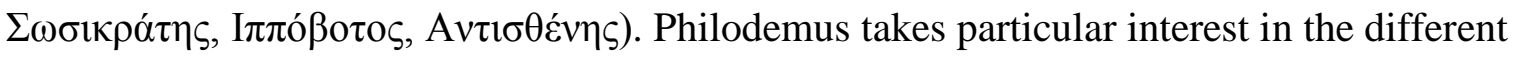
methods of succession for Academic scholarchs ( $\sigma \chi 0 \lambda \alpha \dot{\alpha} \rho \chi \varepsilon \varsigma)$ : we learn that Speusippus inherited the headship directly from Plato, whereas a little later Xenocrates was voted in by the young members of the school; in the mid-third century BC the young members also voted for a certain Socratides ( $\Sigma \omega \kappa \rho \alpha \tau i \delta \eta \varsigma)$ on the basis that he was the eldest, but he ceded the headship to Arcesilaus. Later still, Clitomachus 'burst into' the Academy with his own followers, after having taught for a while at a different location, the Palladium gymnasium. But the 'Successions' genre and Philodemus' own take on it was not only about who followed who (and how) as head of the school; there was also a keen interest to establish an unbroken line of teacher-pupil connections and classify everyone who was ever a member of the Academy, even the less prominent individuals that we know nothing about from other sources. In total, there are upwards of 150 names of Academic philosophers to be found in Philodemus' history.

It seems to me that there are two sides to this trend: on the one hand it goes back to the drive for exhaustive cataloguing and all-inclusive systematisation as practised by the scholars working in Alexandria. I am thinking here of the tradition initiated mainly by Callimachus' Pinakes, and later on the systematic chronological investigations by Apollodorus of Athens, whose Xpovıкá ('Chronology') provided the basis for sequential narratives (and was heavily used by Philodemus as we saw above). This emphasis on exhaustiveness and systematisation could sometimes lead to arbitrary postulation of teacher-pupil relations, in the effort to 'fit everyone in' and emphasise the unbroken continuity of Greek philosophy. All this applies to Philodemus' history of the Academy, and as several scholars have noted, it is in a way part of the Hellenistic tradition I have been describing. On the other hand, we should also recall David Sedley's ${ }^{5}$ argument that Philodemus' Syntaxis is representative of the end-of-an-era atmosphere that prevailed in first-century BC philosophy as the Athenian schools closed or declined and philosophers moved to other emerging cultural centres. The Syntaxis gives the impression not only that the schools have passed through an unbroken continuous succession up to first century BC, but also, as Sedley noted, that this history is coming to an end just as Philodemus is writing in the first century. Of course he could not write about developments

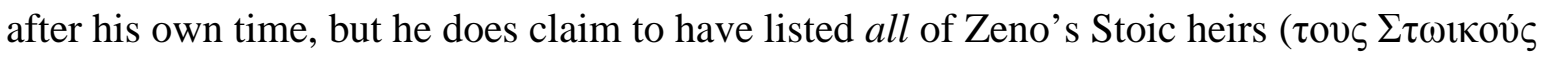

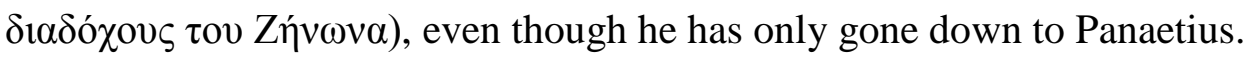

\footnotetext{
${ }^{5}$ D. Sedley, 'Philodemus and the decentralisation of philosophy', CErc 33 (2003): 31-41.
} 
The situation is somewhat more complicated in the book on the Academy: the last person

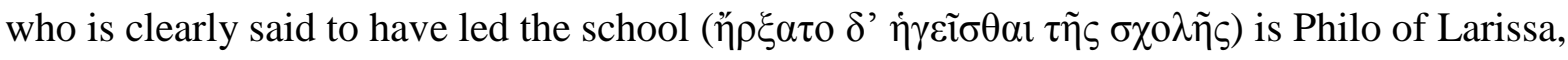
yet Philodemus continues with some remarks on Antiochus of Ascalon and a group of philosophers who apparently were not based in Athens but traveled around ( $\pi \lambda \alpha v \omega ́ \mu \varepsilon v o r)-$ and the ending is not as clear cut as that on the Stoa. Still, the way in which things peter out in the final column with seemingly 'left-over' names that need to be connected somehow to a teacher does suggest that Philodemus did not believe that anyone had any serious claim to be running the Academy at the time when he was writing, between 60 and $50 \mathrm{BC}$.

Let me sum up what we have seen so far: Philodemus' history of the Academy is a series of biographical notes on prominent Academics, not only scholarchs, with a special interest in listing their pupils and providing a comprehensive prosopography of everyone connected with the Academy, from Plato to Antiochus of Ascalon. This approach was dictated firstly by Philodemus' sources and the 'Successions' tradition within which he was working, and secondly by his own concern to provide 'the full story' from the standpoint of looking back at an institution that has more or less run its course. How should we react to this in terms of an assessment of the evidence value for Plato's Academy? First of all we may remark that Philodemus' presentation of a single history of one philosophical school with emphasis on succession and continuity creates a picture of unity which was and is controversial. Things might have been different if Philodemus had expounded a bit more on the thought and philosophical positions of the individuals he discusses, but doxography is largely absent from the text as we have it (and the same applies to the history of the Stoa). This absence of doxography also accounts for a sense of objectivity and impartiality prevalent throughout the surviving portions of the Syntaxis, which has surprised modern scholars expecting Epicurean polemics against the rival schools.

So in the remainder of this paper I will try to address these questions: is there a unified Academy to be found in Philodemus' pages? Is there any doxography? How relevant is Philodemus' Epicurean background? The discussion of these points will then lead me to two further important features emerging from Philodemus' presentation of the Academy, relating to questions of philosophical affiliation and to the role of written texts.

There are two responses to the question of unity, one from the point of view of physical institutional history or even geography, and another more ideological or philosophical. I will touch upon the latter when I come to the problem of doxography, but for now I would like to 
draw attention to some instances where Philodemus speaks quite clearly of physical splits, with Academics distancing themselves from the location of the Academy in order to form their own teaching ventures elsewhere. Firstly, at the time of the vote for the succession of Speusippus we learn that one possible rival to Xenocrates, namely Aristotle, was away in Macedonia - but the other two rivals who did stand for the headship were sorely disappointed by the outcome and left the school. Heracleides left for the Pontus, but Menedemus of Pyrrha

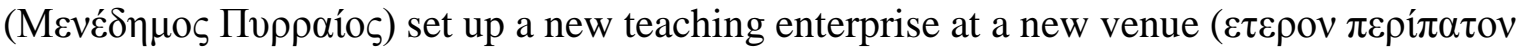

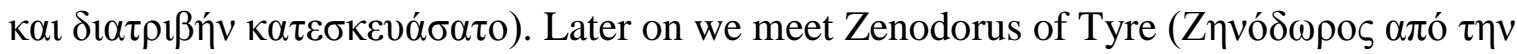
Túpo), a pupil of Carneades (second century BC), who taught at Alexandria (taking $\dot{\eta} \gamma \eta \sigma \alpha ́ \mu \varepsilon v o \varsigma$ in a sense close to $\kappa \alpha \theta \eta \gamma \eta \sigma \alpha ́ \mu \varepsilon v o \varsigma$, without any implication of a continuing school). This 'internationalisation' of Academic teaching is of particular interest, and it may be connected to the number of Alexandrians who joined the Academy in subsequent

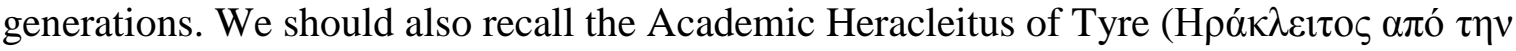
Túpo), a pupil of Philo’s, who is said by Cicero to have been staying at Alexandria when

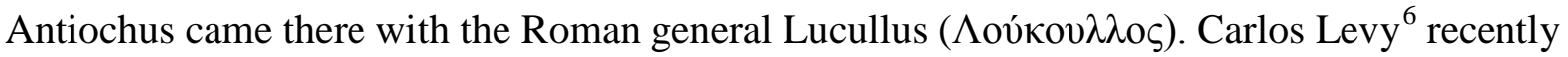
described this situation as a 'network bringing Alexandrian students to Athens'.

Centrifugal tendencies became more pronounced in the later periods of the Academy's history, with Clitomachus setting up his own school at a different gymnasium, the Palladium from where, as we saw above, he forced his way back into the Academy. In the long extract that Philodemus quotes verbatim from Apollodorus of Athens in iambic trimeters ( $\sigma \varepsilon 1 \alpha \mu \beta 1 \kappa o ́$ $\tau \rho i ́ \mu \varepsilon \tau \rho o$ ), we learn of a pupil of Carneades' (the name is missing in the papyrus, it could be Charmadas, X $\alpha \rho \mu \alpha ́ \delta \alpha \varsigma)$ who was so impressive that he received Athenian citizenship and was allowed to teach at yet another gymnasium, the Ptolemaeum. This Ptolemaeum was also the place where Cicero heard Antiochus of Ascalon in the early 70s BC. Other Academics taught further afield still, outside the city walls. Thus we can see that for Philodemus the history of the Academy included not only the activity taking place in the actual gymnasium of that name, but also derivative or even dissenting ventures elsewhere.

The mention of dissent brings me to the problem of all these people's philosophical attitudes and the question of doxography. Philodemus can hardly be called a historian of philosophy if all he did was list Academics and their pupils with the odd anecdote about their lives and nothing on what they thought or taught. Yet several scholars have supposed that there was no doxography in the Syntaxis because none survives in the extant sections.

\footnotetext{
${ }^{6}$ C. Lévy, 'Other followers of Antiochus’ in D. Sedley (ed.) The Philosophy of Antiochus. CUP 2012: 290-306
} 
Sedley ${ }^{7}$ has called this into question, arguing that since the papyrus preserving the history of the Stoa has the biography of Zeno, the founder of the Stoa, in the middle of the roll, the missing first part must have been doxographical. He did not find it as easy to make the same argument for the history of the Academy that concerns us here, because the roll in question (PHerc 1021) seems to have contained the Megarics as well. Be that as it may, the sheer pace and brevity with which Philodemus runs through the lives of all the Academics and Stoics in the surviving portions of the text (each of these major schools occupies less than a full book) makes one wonder what else he could have filled the ten or more books of his Syntaxis with, if not doxographical material.

Of course it is practically impossible to tell what such putative doxographical sections looked like - we can only speculate, for instance, that some Epicurean critiques of other schools' positions might have surfaced there. From the parts of the history of the Academy that we can read, we have some references to individuals' philosophical attitudes, but these are often meant as an illustration of behaviour or character traits; for example, Polemo (Пo $\varepsilon_{\varepsilon} \mu \omega v$ ) disapproved of eristic questioning and insisted that training in argument should be based on concrete facts. According to Philodemus, this made him particularly severe and intolerant of witticisms. Arcesilaus' refusal to put forward any doctrine allegedly had an impact on his associates' demeanour, causing some to be more modest and reserved, and yet more others to adopt an arrogant and aggressive stance.

In one case Philodemus reports a very specific doxographical claim, complete with the

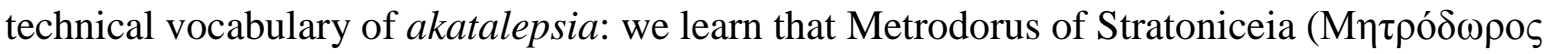
$\Sigma \tau \rho \alpha \tau o v \imath \kappa \varepsilon v ́ \varsigma)$ accused everyone of having misunderstood Carneades, whereas the latter had never believed that all things are inapprehensible. In this Philodemus is in agreement with St

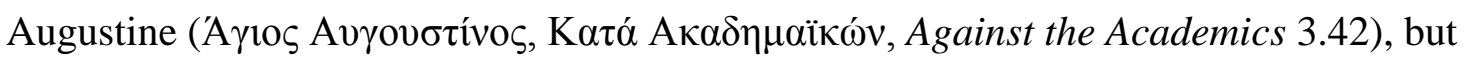
appears to be in conflict with what Cicero says at Lucullus 78 and with Charles Brittain's interpretation of Philo and Metrodorus as genuine sceptics. For Cicero and Brittain, Metrodorus and Philo understood Carneades as supporting universal akatalepsia ( $\alpha \kappa \alpha \tau \alpha \lambda \eta \psi i ́ \alpha)$ and yet allowing that a wise man may hold opinions. As well as noting this type of dissent in the later years of the Academy, Philodemus appears also to be aware of the different phases of the Academy that we find in later doxographical sources such as Diogenes Laertius and Sextus Empiricus: he refers to the 'middle Academy' that was reorganised by

\footnotetext{
${ }^{7}$ D. Sedley, 'Philodemus and the decentralisation of philosophy', CErc 33 (2003): 31-41.
} 
Lacydes, ( $\Lambda \alpha \kappa v ́ \delta \eta \varsigma)$ in such a way that it was called 'new', and he is also aware of the name 'Old Academy' that Antiochus of Ascalon gave to his own group.

So much for the doxographical/philosophical content of the surviving portion from Philodemus on the Academy. I have already suggested that any Epicurean polemics could have appeared in separate doxographical sections, now lost. So if we consider Philodemus' identity as an Epicurean from the biographical point of view of the surviving parts of the Syntaxis, we get a picture of peaceful co-existence and friendly relationships on a personal level across the various schools, as Gigante ${ }^{8}$ has observed. This is nowhere more evident than in Philodemus' own personal relationship with Antiochus and his pupils. Already from the earlier editions of the text it was clear that Philodemus was friendly with the group of Antiochus' pupils ('our friends', $\sigma v v \eta ́ \theta \varepsilon ı \varsigma ~ \eta \mu \omega v$ ) - but Blank’s recent new readings from the papyrus show the close personal contact and mutual affection between Philodemus and Antiochus himself. ${ }^{9}$ Here we can also compare Philodemus' reference to the Stoic Apollonius

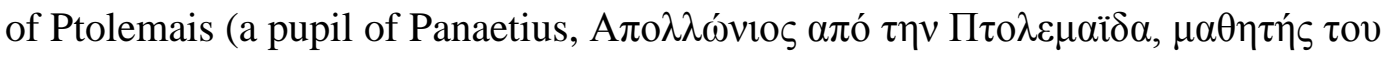

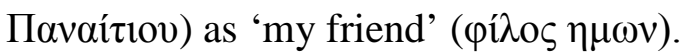

Therefore there does not appear to have been any cause for polemics against other schools on a personal level. Is then Philodemus' identity as an Epicurean relevant in any way? I find quite attractive Gigante's response to this, which takes account of the entire Syntaxis as one project. Gigante saw this project as an 'institutional manual', a way of 'packaging' Greek philosophy in a concise systematic form, targeted at his Italian audience. Crucially, the Syntaxis included a section on the Epicurean school (as we saw in the initial quotation from Diogenes Laertius), placing it firmly on the map of Greek philosophy on a par with schools like the Academy. There is not unanimous agreement among modern scholars as to whether the Syntaxis was indeed intended for Roman newcomers to Greek philosophy or internally for Epicurean converts, or indeed as to whether he portrayed the Garden as somehow superior to the other schools. But it provided Philodemus with an opportunity to assert and legitimise the position of the Epicurean school relative to other schools, as well as his version of the Epicurean succession.

I have already touched upon Philodemus' evidence for friendly personal relationships among philosophers belonging to different schools. To this I would like to connect his evidence for more widespread crossover and migration from one school to another, which

\footnotetext{
${ }^{8}$ M. Gigante, Philodemus in Italy: The Books from Herculaneum (transl. D. Obbink). Ann Arbor: 2002

${ }^{9}$ D. Blank, 'The life of Antiochus of Ascalon in Philodemus' History of the Academy and a tale of two letters', ZPE 162 (2007): 87-93.
} 
shows that the Academy was not a closed system of exclusive membership, and different Academics could come from different philosophical backgrounds or indeed end up at different schools. In the early years there must have been some overlap between the Academy and Aristotle’s Peripatos, with some people having studied both with Plato or Speusippus and

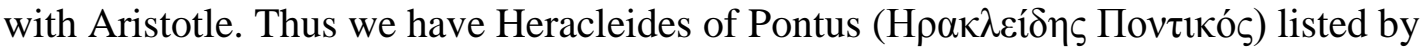
Philodemus as an Academic, even as one who aspired to the headship of the Academy, whereas Diogenes Laertius discusses him among the Peripatetics. Arcesilaus, too, came across from the school of Theophrastus in the early $3^{\text {rd }}$ century BC and remarked that by comparison Polemo and the Academics seemed like gods or humans of the golden race (this

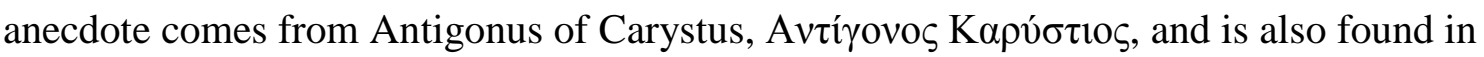
Diogenes). Among the pupils of Arcesilaus there is a reference to a $\mu \varepsilon \tau \alpha \theta \varepsilon \dot{\varepsilon} \mu \varepsilon v o s$, who eventually posited pleasure as the final end. Perhaps it is the same notorious Dionysius 'the defector', who is elsewhere said to have changed from the Stoa to Cyrenaics or the Epicureans (according to Athenaeus). If he also studied with Arcesilaus it would bring the number of schools he sampled up to at least three.

There was traffic in the opposite direction as well, with Metrodorus of Stratonicea joining the Academy from the Epicurean school in the second half of the $2^{\text {nd }}$ century BC, because apparently he had been pushed away by Apollodorus the ‘tyrant of the Garden’. Finally, we have the famous case of Antiochus' two pupils, Aristo and Cratippus, who became Peripatetics, but doubtless we will hear more about them in later sessions.

The final point I would like to touch upon in terms of the evidence that Philodemus provides for the history of the Academy relates to the circulation of written texts. At the very

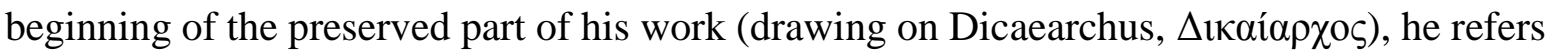
to the great influence, both positive and negative, that was exercised by Plato on the development of philosophy precisely through the availability of his written dialogues. According to Antigonus of Carystus in his Life of Zeno (cited by Diogenes), the works were freshly made available just as Zeno came to Athens from Cyprus towards the end of the fourth century.

From the mid- $3^{\text {rd }}$ century, as the Academy turned towards scepticism, there was a growing tendency for scholarchs not to leave behind any writings of their own. Arcesilaus in particular is said not to have written any books because he suspended judgement on all matters. There are, however, reports that Arcesilaus was caught red-handed altering some works or $v \pi о \mu v \eta \dot{\mu} \mu \alpha \alpha$ by Crantor, at which point sources disagree on whether he published or burnt them. Such reports invite questions about Arcesilaus’ possible motives, given his innovative 
sceptical turn - what was he hoping to gain by altering Crantor's views? They also raise a problem of reliability, which permeates down to the later centuries of the Academy, as almost every scholarch now has his lectures taken down in the form of notes by one of his pupils rather than publishing himself. This practice placed Zeno of Alexandria in a particularly difficult position: he wrote notes from the lectures of Carneades but was publicly and forcefully rebuked by the master over their inaccuracy. Hagnon of Tarsus ('A $\gamma \nu \omega v$ T $\alpha \rho \sigma \varepsilon v ́ \varsigma$ ) did a better job of it and was accordingly praised. This questionable transmission of philosophical views whereby one cannot be certain what their originator thought or what argument he made (we may recall here how Metrodorus was able to claim that Carneades had been misunderstood by all) stands in stark contrast to the premium placed on authoritative foundational and classical texts from the $1^{\text {st }}$ century BC. Perhaps it would not be too farfetched to claim that this impression of doubt and uncertainty is an appropriate one for the sceptical Academy that denied the possibility of certain knowledge.

In conclusion, Philodemus' history of Academy brings to light or draws our attention afresh to some valuable pieces of evidence about Plato’s Academy: it introduces us, albeit briefly and partially, to 150 or so of its members, all organised in systematic teacher-pupil successions, with the occasional detail about succession procedures, and conveying an awareness that these successions have more or less come to their end. Philodemus' work does not tell us much about what these Academics thought, but it raises some interesting questions about the unity of the Academy, the relationship of Academics with other schools and the extent to which the views of prominent scholarchs are recoverable. The precarious transmission of the text does not permit us to go much further, so the precise framework in which Philodemus placed his history and its relationship with the sections on the Stoa and the Garden remains out of our reach until, perhaps, archaeology and technology provide us with fuller texts. 